\title{
TRADITIONAL BONE SETTING PRACTICE OF RABHA PEOPLE OF ASSAM
}

\section{TAPAN DUTTA ${ }^{1,2}$, PINAKI KUMAR RABHA ${ }^{2}$, REKHA BORA ${ }^{1 *}$, JAYASHREE GOSWAMI ${ }^{1}$, SEEMA KHAKHALARY ${ }^{1}$}

${ }^{1}$ Advanced Level Institutional Biotech Hub, Jawaharlal Nehru College, Boko, Assam, India. ${ }^{2}$ Department of Botany, Jawaharlal Nehru College, Boko, Assam, India. Email: rekha.bora969@gmail.com

Received: 24 July 2018, Revised and Accepted: 25 August 2018

ABSTRACT

Objective: The aim of this work is to document the various ethnomedicinal healing plant species used in traditional bone setting (TBS) practice of Rabha community of Assam.

Methods: This has been done using interview method which includes semi-structured questionnaire and the field walks method.

Results: The results reveal that eight healing plants wear employed to in the TBS practice. Among these, Cissus quadrangularis L. is the most commonly used plant species to treat bone fracture. In this study, two modes of preparation for the ethnomedicine have been served (i.e., paste and extract) where paste form has higher used (75\%).

Conclusions: It has been concluded that Rabha Hasong area of Assam is indeed rich in ethnomedicinal plants. People get benefited from the traditional practices performed by the medicine men. This is the chief reason TBS practice that is still running smoothly with full faith and hope even in the current time where sophisticated orthopedic treatments are obtainable. Moreover, systematic nutraceutical appraisal of these species would provide a remarkable research possibility in the fields of ethnopharmacology that would be useful in the modern orthopedic treatments.

Keywords: Ethnomedicine, Rabha Hasong autonomous council area, Rabha tribe, Traditional bone setting practice.

(C) 2019 The Authors. Published by Innovare Academic Sciences Pvt Ltd. This is an open access article under the CC BY license (http://creativecommons. org/licenses/by/4. 0/) DOI: http://dx.doi.org/10.22159/ajpcr.2019.v12i1.28671

\section{INTRODUCTION}

Ethnomedicinal practices are still unable to catch enough patronage by the laypeople of India. These have diverse biological efficiencies that contribute to pharmacological research and food industries [1-3]. Alarge number of ethnic communities are dwelling in India which are blessed with significant and diverse sociocultural and ethnic identities [4]. Each community has a unique grip of traditional belief and wise practice for health necessities. Therapeutic herbs play an inimitable role in this traditional knowledge system which is practiced and equally benefited by a remarkable number of folks $[5,6]$. Something like 70,000 bone setters in India are engaged in traditional bone setting (TBS) practice. They are practicing it without any principles of modern orthopedics study and other traditional practices such as Ayurveda, Homeopathy, and Unani but using their own methodology and ideas. Moreover, the treatment process of TBS practice has commenced without any prediagnosis of the disorder like X-ray evaluation. Therefore, this is considered one of the noteworthy traditional practices of India. This has been practiced widely in different parts of India such as Tamil Nadu, Andhra Pradesh, Kerala, Karnataka, Assam, and West Bengal [7-9]

The Rabha Hasong Autonomous Council area located in between $25^{\circ}$ 53 and $26^{\circ} 49 / \mathrm{N}$ latitude and $90^{\circ} 07 /$ and $91^{\circ} 50 / \mathrm{E}$ longitude. It has an area of $3161^{2} \mathrm{~km}$ covering two districts with 823 villages. Among Schedule Tribe, Rabha, Bodo, Garo, and Hajong people are dwelling in that area.

The Rabha people are maintaining their traditional distinctiveness of sociocultural fabrics with characteristics religious belief and practices, festivals, language, culture, etc. Beyond Assam, they are found in Meghalaya, Manipur, West Bengal, and even in two neighboring countries, Nepal and Bangladesh. In Assam, they are mostly distributed in Kamrup and Goalpara district (called Rabha Hasong Autonomous Council) and few patches of Darrang district [10]. Rabha tribe has nine subtribes with individual dialect and customs. These are - Rangdani, Maitori, Pati, Dahuri, Koch, Hana, Tolta, Bitliya, and Shonga.
Bone is the unbend organ which is the great support and guard of the skeleton that provides proper strength to the vertebrate body. Unfortunately, due to some accidental incidents, it may cause severe bone fracture. Most of them have less interest toward the painful modern orthopedic treatments. Interestingly, some ethnic communities involve in TBS practice those provide a great relief and hope to the sufferer. The current work is, therefore, formulated to unveil some healing plants used by the "traditional bone setter" of Rabha tribe in their TBS practice.

\section{Study site}

The present study site comprises four places of Kamrup district, Rani, Hazipara, Dakuapara, and Langkona and two of Goalpara district, Rongjuli and Dhupdhara (Fig. 1).

\section{METHODS}

A survey has been carried out during the months from July to December 2017. Information was gathered from traditional bone setters who have a good knowledge of the utilization of plants as herbal medicine. The Rabha people of those areas are influenced by Assamese culture as well as language, thus no interpreters were employed. Interviews were followed by the standard method of Martin [11] and Maundu [12] which were semi-structured questionnaire and the field walks method. Information for the TBS practice has been included the name of the plant, part of the plant being used, form of the medicine, preparation processes of medicine, etc. The specimens were collected along with its reproductive parts for their appropriate identification. Photographs were also obliging that were captured in a natural habitat. The list of the ethnomedicinal plant names along with their local names, family names, used plant parts, voucher numbers, and medicinal uses has been presented in tabular form (Table 1). The collected specimens were preserved in the Department of Botany, J. N. College, Boko, Assam.

\section{RESULTS AND DISCUSSION}

The present study has unveiled total eight healing plants from eight different families for TBS practice. Among these, only Cissus 
Table 1: List of ethnomedicinal plants used in TBS practice in Rabha Hasong autonomous council Area, Assam

\begin{tabular}{|c|c|c|c|c|c|c|}
\hline S.no & Scientific name & Family & Local name & Voucher no & Parts used & Mode of preparation \\
\hline 1. & A. aspera L. & Amaranthaceae & Ucktishar & JNC001 & Root & Paste \\
\hline 2. & A. indica $\mathrm{L}$. & Aristolochiaceae & Nilakantha & JNC002 & Leaf, stem, root & Paste \\
\hline 3. & C. quadrangularis $\mathrm{L}$. & Vitaceae & Harjora lota & JNC003 & Stem & Paste \\
\hline 4. & C. buchanani. Roem. and Schult. & Asclepiadaceae & Ananta mul (Kala) & JNC004 & Root & Paste \\
\hline 5. & Curcuma longa Linn & Zingiberaceae & Haldi & JNC005 & Rhizome & Paste \\
\hline 6. & H. antidysenterica (L.) Wall. ex A. DC. & Apocynaceae & Dudhkhuri & JNC006 & Bark & Water extract \\
\hline 7. & Justicia gendarussa Linn. & Acanthaceae & Tita bahak & JNC007 & Shoot & Paste \\
\hline
\end{tabular}

A. aspera: Achyranthes aspera, A. indica: Aristolochia indica, C. quadrangularis: Cissus quadrangularis, C. buchanani: Cryptolepis buchanani, H. antidysenterica: Holarrhena antidysenterica, L. chinensis: Litsea chinensis, TBS: Traditional bone setting

quadrangularis $\mathrm{L}$. is the mostly consumed plant species by different traditional bone setters [13-17]. Other two, Achyranthes aspera L. and Cryptolepis buchanani Roem. and Schult., are very less applied for this practice. Whereas, Aristolochia indica L., Holarrhena antidysenterica (L.) Wall. ex A. DC., and Litsea chinensis Lam. are found to be first reported. The herbal medicines prescribed by the traditional bone setters here are in monoherbal formulation which makes these medicines less complicated and easier to collect and cultivate. Results are observed within 1-2 months although sometimes take 6 months for extreme cases. Clean and a thin cotton band with the herbal medicine is wrapping the injured area. After absorbing the medicinal extract by the fractured body part (takes 2-3 days), the band needs to remove. This "wrapping therapy" has continued till the positive result has observed which is conducted under the observation of experienced traditional bone setter. The current study shows that the majority of mode of preparation for the ethnomedicine is in the form of pastes, i.e., $75 \%$ (6 of 8 healing plant species) which facilitate to prepare the herbal medicine effortlessly. Percentage of medicinal plant parts are calculated and shown in (Fig. 2). This figure has exhibited that $12.50 \%$ of leaf, shoot, and rhizome; $25.00 \%$ of stem and bark; and $37.50 \%$ of root are found to treat the bone fracture.

Short descriptions of some plants used in TBS practice are as follows: A. aspera L.: It is an erect, annual, or perennial herb, reach up to $0.5-1.5 \mathrm{~m}$. Plant is a very remarkably used traditional herb [18-20]. However, only few report of the plant has recorded regarding the TBS practice [21]. This plant has a large number of bioactivities such as antiarthritic, antifertility, ecbolic, abortifacient, antitumor, antihelminthic, antimicrobial, antiviral, antiplasmodic, aphrodisiac, antihypertensive, and anticoagulant [20].

A. indica L.: It is a shrub or perennial herb, linear-oblong to obovateoblong leaves, inflorescence axillary racemes; bracts ovate, seed deltoid-ovate, flat, winged [22]. Other significant bioactivities of this plant are anticancer, abortifacient, antimicrobial, anti-inflammatory, antipyretic, antifertility, etc. [23].

C. quadrangularis L.: It is a climber growing with tendrils leaves simple broad-ovate stems quadrangular, succulent with angles winged, each node bears a tendril, and flowers are whitish in hue. This plant is well-known traditional medicine in bone fracture. This plant is used in other traditional health practices such as weight loss, digestion troubles, reproductive problems, antimicrobial, analgesic, antipyretic, anti-inflammatory, tissue defensive, and enlarging lean muscle mass [16]

C. buchanani Roem. and Schult. (Three synonyms, Cryptolepis dubia, Cryptolepis reticulata, Periploca dubia): It is useful in bone fracture as also been reported by Tayung and Saikia, 2003. Plant is a hefty climbing shrub, leaves elliptic, oblong, or oblong-lanceolate, stem cylindrical, branches pale, latex occur, flowers are pale greenishyellow inflorescence axillary panicled cymes, and seeds are ovateoblong. Plant is used as tonic and beneficial in anorexia, leprosy, and rickets of children. Moreover, it is act as antipyretic, antimicrobial, and blood purifier [24].

H. antidysenterica (L.) Wall. ex A. DC.: It is a shrub or small tree, available in most of the parts of India, mostly in Sub-Himalayan regions. The bark is slight rough, leaves opposite, subsessile, elliptic

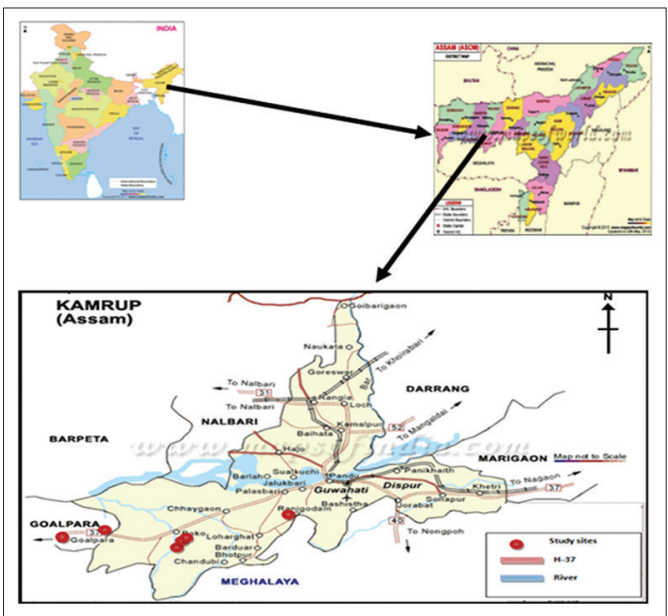

Fig. 1: Geographical map showing study sites

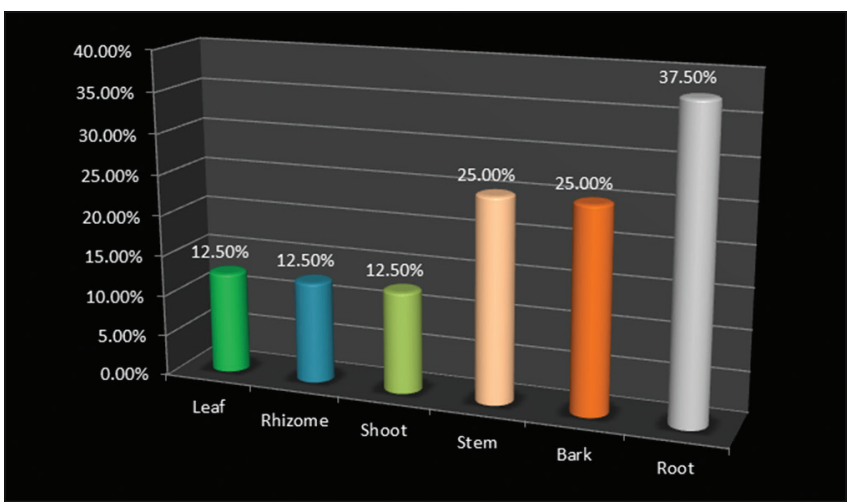

Fig. 2: Percentage of medicinal plant parts utilized in traditional bone setting practice

or ovate-oblong; inflorescence terminal corymbose, flowers white in color, and seeds are light brown [25]. Plant is useful in diarrhea, dysentery, constipation, hypertension, and urethritis also acts as astringent, cardiosuppressant, etc., [26].

L. chinensis Lam.: Synonyms are L. glutinosa (Lour.) C. B. Rob., L. citrifolia Juss., L. fruticosa Span. ex Bl., L. multiflora Bl., etc. [27]. This plant has different medicinal properties such as wound healing, antidiarrheal, and anti-inflammatory [28].

This work discloses and focuses on TBS practice of Rabha community of Assam which is an ancient health practice. It has some similarities with "Puttur kattu," a TBS practice in South India in Panda and Rout [7]. The paste of Cassia occidentalis plant is widely used for the bandage in "Puttur kattu" practice [7]. As suggested by Dada et al., 2011 [29], it is an effective and useful practice; where our study also demands that the practice should be improved by some more skillful modern trainings, peer observation, and attention. 


\section{CONCLUSION}

From this study, it can be concluded that Rabha Hasong area of Assam is indeed rich in ethnomedicinal plants. People get benefited by the traditional practices performed by the medicine men. This is the chief reason for which TBS practice is still running smoothly with full faith and hopes even though sophisticated orthopedic treatments are available. Moreover, if systematic nutraceutical evaluation of these healing plants involves in TBS practice, it would provide a promising scope to the future pharmacological research on modern orthopedic techniques. This will also confer a proper scientific authentication to this practice.

\section{ACKNOWLEDGMENT}

The authors are thankful to DBT, Government of India, for funding the research work and also grateful to the local people and traditional bone setters of the survey areas.

\section{AUTHORS' CONTRIBUTIONS}

- Conception and design of the study: Bora R, Dutta T, and Rabha PK.

- Interpretation of data and revising the manuscript: Bora R, Dutta T, Goswami J, and Khakhalary S.

\section{CONFLICTS OF INTEREST}

The authors declare that they have no conflicts of interest.

\section{REFERENCES}

1. Kumari S. Evaluation of phytochemical analysis and antioxidant and antifungal activity of Pithecellobium dulce Leaves' extract. Asian J Pharm Clin Res 2017;10:370-5.

2. Lestari MW, Soemardji AA, Fidrianny I. Review of traditional use, pharmacological effects, and toxicity of medicinal plants for women's health in Indonesia. Asian J Pharm Clin Res 2016;9:41-6.

3. Soni A, Dahiya P. Screening of phytochemicals and antimicrobial potential of extracts of Vetiver zizanoides and Phragmites karka against clinical isolates. Int J Appl Pharm 2015;7:22-4.

4. Periyasamy K, Kaliyaperumal S. Ethnobotanical, phytochemical and pharmceutical studies of medicinal plant, Ventilago maderaspatana Gaertn (Red creeper): A review. Int J Curr Pharm Res 2016;8:16-8.

5. Kaur M, Singhal VK, Singh J. Use of some ethnomedicinal herbs by the natives of Solang valley, Kullu District, Himachal Pradesh. Int J Pharm Pharm Sci 2017;9:222-7.

6. Sasi S, Anjum N, Tripathi YC. Ethnomedicinal, phytochemical and pharmacological aspects of Flacourtia jangomas: A review. Int J Pharm Pharm Sci 2018;10:91-115.

7. Panda AK, Rout S. Puttur kattu (bandage)-a traditional bone setting practice in south India. J Ayur Integr Med 2011;2:174-8.

8. Tayung K, Saikia N. Cryptolepis buchanani - A less-known medicinal plant in bone fracture. Ind J Trad Know 2003;2:371-4.
9. Roychowdhury S. Reviewing the place of traditional orthopaedic practitioners in rural Bengal's health care scenario: A study on Rajbanshis of Coochbehar District, West Bengal, India. Int Res J Social Sci 2016;5:6-10.

10. Bora R, Das AK. An inventory of ethnomedicinal plants among the Rabha Tribe residing nearby Chandubi Beel of Kamrup District (Assam). Int J Innov Res Sci Tech 2015;1:126-9.

11. Martin GJ. Ethnobotany: A 'People and Plants' Conservation Manual. London: Chapman and Hall; 1995.

12. Maundu P. Methodology for collecting and sharing indigenous knowledge: A case study. Ind Know Devt Monit 1995;3:3-5.

13. Kumar TS, Jegadeesan M. Physico-chemical profile of Cissus quadrangularis 1. Var-i in different soils. Anc Sci Life 2006;26:50-8

14. Gupta AK, Sharma M. Cissus quadrangularis L. Rev. Indian Med Plants 2008;6:410-1

15. Deka DK, Lahon LC, Saika J, Mukit A. Effect of Cissus quadrangularis in accelerating healing process of experimentally fractured radius-ulna of dog: A preliminary study. Indian J Pharm 1994;26:44-5.

16. Stohs SJ, Ray SD. A review and evaluation of the efficacy and safety of Cissus quadrangularis extracts. Phytother Res 2012;2012:1-8.

17. Managutti AM, Shah DN, Patel JC, Puttanikar NY, Shah DS, Managutti SA. Evaluation of clinical efficacy of Cissus quadrangularis in pain management and bone healing after implant placement: A pilot study. Int J Oral Implantol Clin Res 2015;6:35-9.

18. Suresh A, Anandan T, Sivanandam G, Veluchamy G. A pilot study of naayuruvi kuzhi thailam in eraippunoi (bronchial asthma). J Res Ayur Siddha 1985;6:171-6.

19. Reddy MB, Reddy KR, Reddy MN. A survey of plant crude drugs of Anantpur district, Andhra Pradesh, India. Int J Crude Drug Res 1989;27:145-55

20. Hasan, S. Pharmacological and medicinal uses of Achyranthes aspera. Int J Sci Tech 2014;3:123-9.

21. Gupta V, Krishna CM, Bansal, Kumar S, Prasad GP, Krishna DV. Phytochemistry and pharmacological potential of Achyranthes aspera- a review. Int J Ayur Med 2010;1:1-11.

22. Sati H, Sati B, Saklani S, Bhatt PC, Mishra, AP. Phytochemical and pharmacological potential of Aristolochia indica: A review. Res J Pharm Bio Chem Sci 2011;2:647-54.

23. Dey A, De JN. Aristolochia indica L: A review. Asian J Plant Sci 2011;10:108-16

24. Available from: http://www.vikaspedia.in/agriculture/crop-production/ package-of practices/medicinal-and-aromatic-plants/cryptolepisbuchananii-1.

25. Available from: http://www.la-medicca.com/raw-herbs-holarrhenaantidysenterica.html.

26. Gilani AH, Khan A, Khan A, Bashir S, Rehman N, Mandukhail, S. Pharmacological basis for the medicinal use of Holarrhena antidysenterica in gut motility disorders. Pharm Bio 2010;48:1240-6.

27. Available from: https://www.indiabiodiversity.org/species/show/230244.

28. Bhatt SP, Pandya SS. Scanning electron microscopy of leaf of Litsea chinensis Lam. Int J Res Pharm Chem 2012;2:470-8.

29. Dada AA, Yinusa W, Giwa SO. Review of the practice of traditional bone setting in Nigeria. Afr Health Sci 2011;11:262-5. 